\title{
KNOWLEDGE IN ADOLESCENT GIRLS AND BOYS RELATED TO PHYSICALLY ACTIVE AND HEALTHY LIFESTYLE
}

\author{
Jana Vašíčková, Krystyna Górna-Łukasik*, Dorota Groffik*, Karel Frömel, Krzysztof Skalik*, \\ Zbyněk Svozil, Wojciech Wąsowicz*
}

\author{
Faculty of Physical Culture, Palacký University, Olomouc, Czech Republic \\ * Academy of Physical Education, Katowice, Poland
}

Submitted in December, 2011

BACKGROUND: Knowledge about physically active and healthy lifestyle is one of key factors influencing relationship to physical activity (PA) and to lifetime prevalence of healthy lifestyle in adolescents.

OBJECTIVE: The aim of the study was to identify differences in girls' and boys' knowledge about healthy lifestyle and the strength of the association between the stated weekly physical activity and basic knowledge on healthy lifestyle.

METHODS: The research involved 14 selected schools in the Katowice region, and 275 girls (15.8 \pm 0.9 years) and 220 boys ( $15.8 \pm 0.8$ years $)$ participated in the study. The level of knowledge about healthy lifestyle was assessed using the "Comprehensive test on health and physical activity" and the level of weekly physical activity was assessed using the IPAQ - long version, with repeated measurement after six weeks. The associations between knowledge, sex and meeting PA recommendations (at least $3 \times 20$ minutes of vigorous and $5 \times 30$ min. of moderate weekly PA) were analyzed.

RESULTS: Girls show better knowledge related to physically active and healthy lifestyle than boys $(\mathrm{U}=5.04$; $p=0.000 ; d=0.493)$, which was confirmed in a repeated measurement $(U=5.54 ; p=0.000 ; d=0.505)$. Statistically and practically significant differences between boys and girls were found in favour of girls in the areas of nutrition, education and also overall. Between knowledge and meeting PA recommendations, no significant associations were found either in boys or girls. The boys declared more weekly PA (in the first measurement 11,386 METs and in the second measurement 11,393 METs on average) than girls (in the first measurement 8,891 METs and in the second measurement 9,992 METs on average).

CONCLUSIONS: Basic knowledge on healthy lifestyle is not satisfactory with the regard to the curricular requirements (especially in physical education and biology). Deeper knowledge acquisition about healthy lifestyle requires adapting integral interdisciplinary approach and effective connection between knowledge acquisition about physical activity, diet, and other health and preventive measures and girls' and boys' lifestyle.

Keywords: Physical education, physical activity, Comprehensive test, curricular integration.

\section{INTRODUCTION}

The adoption of healthy lifestyle, positive changes in one's lifestyle, and also maintenance of healthy lifestyle are prompted also by adequate knowledge about key aspects of physically active and healthy lifestyle.

School has the greatest opportunities and duties to provide the "literacy in healthy lifestyle" regardless of the need to educate in this area on life-long basis. Physical education is especially irreplaceable in this education and it should complete several roles in this area, integration, putting into context, application, and verification. Trudeau and Shephard (2008) have pointed that physical education could address more students if there were a greater emphasis exactly on this educational role rather than only on the Competitive aspect of physical activity. Physical education should provide "sports education" enhancing regular participation in
PA and appropriate life-long leisure time physical activities (Mohr, Townsend, \& Pritchard, 2006).

Knowledge acquisition in physical education requires to respect the differences between boys and girls. Boys are more physically active than girls (Gavarry, Giacomoni, Bernard, Seymat, \& Falgairette, 2003; Sanchez, Norman, Sallis, Calfas, Cella, \& Patrick, 2007) and prefer more condition oriented physical activities (Frömel, Formánková, \& Sallis, 2002). Girls prefer especially aesthetically oriented physical activities and are more open to learning. Successful acquisition of knowledge should be more connected to performing favourite and manageable physical activities and manageable ways of their realization.

An important aspect in the identification of the differences in education between boys and girls is given by sex related health and developmental risks. Typical examples are the differences in risks of osteoporosis or cardiovascular diseases. Anderson et al. (2005) point 
at the inadequate knowledge of health and prevention against osteoporosis in girls and they require education intervention to support osteo-protective praxis among adolescent girls. Andersen, Harro, Sardinha, Froberg, Ekelund, Brage et al. (2006) call for the increase of physical activity up to 90 minutes daily which might be necessary for children to prevent insulin resistance, which seems to be the central feature for clustering of cardiovascular disease risk factors.

The interdisciplinary integration and theme integration are on the front burner. The theme integration applies to such topics as PA, energy expenditure and energy income, diet and PA, health and lifestyle, benefits of PA, health and PA, health and diet, etc. Cross-curricular PA and education reducing risks of cardiovascular diseases in youth is also advocated by Knox et al. (2009).

Physical education as an academic subject has greater possibilities to connect school with students' life outside of school than many other subjects. The fact that according to an analysis of studies, the transfer from physical education to leisure time physical activities is not implemented enough (De Meester, van Lenthe, Spittaels, Lien, \& De Bourdeaudhuij, 2009) can present a challenge to adopt progressive concepts of physical education including a new approach to adopt knowledge on physically active and healthy lifestyle.

The aim of research was to identify differences between girls' and boys' knowledge using a standardized Comprehensive test. Further, we were to identify the strength of the association between healthy lifestyle and recommendations for weekly PA.

\section{METHODS}

\section{Participants}

In total, 14 selected schools in the Katowice region and 609 students were addressed to participate in the study. Out of the addressed, 599 participants and their parents gave their consent with the research (in total
8 boys and 2 girls refused to participate). 72 participants were excluded from the pre-test and post-test for not completing or inappropriate completing of the IPAQ questionnaire and 37 participants were excluded for not completing or inappropriate completing of the Comprehensive test. In total, 495 questionnaires were processed, in particular 275 girls ( $15.8 \pm 0.9$ years $)$ and 220 boys ( $15.8 \pm 0.8$ years $)$.

\section{Research techniques}

The level of knowledge about healthy lifestyle was assessed using the Comprehensive test and the level of weekly PA using the "International Physical Activity Questionnaire" (IPAQ) - long version (Craig et al., 2003) (The IPAQ group, n. d.), repeated after six weeks. The associations between knowledge, sex and meeting PA recommendations (at least $3 \times 20$ minutes of vigorous PA and at least $5 \times 30$ minutes of moderate weekly PA) were observed. Good validity and reliability of the IPAQ questionnaire have been confirmed by previous studies (Cerin, Saelens, Sallis, \& Frank, 2006; Saelens, Sallis, Black, \& Chen, 2003). The Polish version of the Comprehensive test and questionnaires have undergone the standard process of "translation and backtranslation" from the English and Czech versions in compliance with the "Guide to cultural adaptation and translation of the IPAQ instruments" (The IPAQ group, n. d.).

The Comprehensive test included 32 questions, ranged in the dimensions of condition, energy, nutrition and education. The standardization of the Comprehensive test included 129 girls and 123 boys at secondary schools, and the coefficient of stability $r_{t t}=.481(p<.01)$ and the coefficient of inner consistence $r_{t t}=.482$ $(\mathrm{p}<.01)$ were identified (Vašíčková, Neuls, \& Frömel, 2011).

\section{Processing of results}

The results of the Comprehensive test and the questionnaire were processed using special registration soft-

\section{TABLE 1}

Basic characteristics of girls and boys meeting or not meeting the PA recommendations

\begin{tabular}{|c|c|c|c|c|c|c|c|c|}
\hline \multirow{3}{*}{ Characteristics } & \multicolumn{4}{|c|}{ Meeting PA recommendations } & \multicolumn{4}{|c|}{ Not meeting PA recommendations } \\
\hline & \multicolumn{2}{|c|}{ Girls $(n=98)$} & \multicolumn{2}{|c|}{ Boys $(n=100)$} & \multicolumn{2}{|c|}{ Girls $(n=177)$} & \multicolumn{2}{|c|}{ Boys $(n=120)$} \\
\hline & $M$ & $S D$ & $M$ & $S D$ & $M$ & $S D$ & $M$ & $S D$ \\
\hline Age (years) & 15.71 & 0.85 & 15.56 & 0.80 & 15.86 & 0.86 & 15.71 & 0.86 \\
\hline Height (cm) & 165.24 & 6.38 & 176.80 & 6.62 & 165.85 & 6.47 & 173.58 & 8.56 \\
\hline Weight (kg) & 54.02 & 7.65 & 67.82 & 11.03 & 56.49 & 8.50 & 65.27 & 12.02 \\
\hline BMI $\left(\mathrm{kg} \times \mathrm{m}^{-2}\right)$ & 19.75 & 2.23 & 21.64 & 2.87 & 20.54 & 2.89 & 21.58 & 3.15 \\
\hline $\begin{array}{l}\text { Total physical activity } \\
\left(\text { MET-min } \times \text { week }^{-1}\right)\end{array}$ & 13,791 & 6,547 & 14,797 & 7,848 & 6,178 & 4,451 & 8,359 & 5,862 \\
\hline
\end{tabular}


ware. Due to incomplete filling, 37 comprehensive tests were excluded from the analysis.

The assessment of the results from the IPAQ questionnaires was done in compliance with the official handbook "Guidelines for data processing and analysis of the international physical activity questionnaire" (The IPAQ group, n. d.). Unlike in the IPAQ handbook, vigorous PA was identified at the level of 6 METs. Due to incomplete or inappropriate filling, 72 questionnaires were excluded in the pre-test and post-test.

The values of the IPAQ long questionnaire were used to divide the participants into categories of those who meet and who do not meet the recommendations for daily physical activity (Bauman, Bull, Chey, Craig, Ainsworth, Sallis et al., 2009). Those who met at least $3 \times 20$ minutes of vigorous PA and at least $5 \times 30 \mathrm{minu}-$ tes of moderate weekly PA were classified into category "meeting recommendation for PA". The rest of adolescents were classified as "not meeting recommendation for PA”.

\section{Statistical analyses}

In order to statistically process the data, we used the Statistica 8 program and the basic statistical values Kruskal-Wallis test, Mann-Whitney U test, and also "effect size" coefficients d (Cohen, 1988) and $\eta^{2}$ (Sheskin, 2007).

\section{RESULTS}

Between girls who meet recommendations for PA and who do not meet them, no significant differences were found in knowledge related to physically active and healthy lifestyle (TABLE 2). The same applies to boys. Girls in both groups have shown better knowledge than boys in dimension of nutrition, education, and in total. The nutrition dimension describes mainly energy balance between food intake and output in a form of various PA and some rules about nutrition. The education dimension comprises questions about general knowledge that are mostly part of the biology or health education curricula.

The results of repeated survey have completely confirmed the results of the introductory survey. It is obvious that general knowledge related to physically active and healthy lifestyle is not associated with PA level.

Also in total, girls showed better knowledge related to physically active and healthy lifestyle than boys, both in the first survey, and also in the second survey (Fig. 1). Significant differences were found in the first survey in the dimensions of condition $(\mathrm{U}=2.07 ; \mathrm{p}=0.038$; $\mathrm{d}=0.19)$, and nutrition $(\mathrm{U}=5.58 ; \mathrm{p}=0.000 ; \mathrm{d}=0.50)$, education $(\mathrm{U}=4.18 ; \mathrm{p}=0.000 ; \mathrm{d}=0.38)$ and in total $(\mathrm{U}=5.54 ; \mathrm{p}=0.000 ; \mathrm{d}=0.50)$. The condition dimension is about regularity in physical conditioning and fitness.

\section{TABLE 2}

Knowledge related to healthy lifestyle in girls and boys meeting health recommendations for physical activity (at least $3 \times 20$ minutes of vigorous and at least $5 \times 30$ minutes of moderate weekly PA) in the first and the second measurement

\begin{tabular}{|c|c|c|c|c|c|c|c|c|c|c|c|c|}
\hline \multirow{4}{*}{ Dimension } & \multirow{4}{*}{ Measurement } & \multicolumn{8}{|c|}{ Meet recommendations for PA } & \multirow{4}{*}{$\mathbf{H}$} & \multirow{4}{*}{$\mathbf{p}$} & \multirow{4}{*}{$\eta^{2}$} \\
\hline & & \multicolumn{4}{|c|}{ Girls $(n=275)$} & \multicolumn{4}{|c|}{ Boys $(n=220)$} & & & \\
\hline & & \multicolumn{2}{|c|}{$\begin{array}{c}\text { Yes } \\
\left(\mathrm{n}_{1}=98\right) \\
\left(\mathrm{n}_{2}=99\right)\end{array}$} & \multicolumn{2}{|c|}{$\begin{array}{c}\text { No } \\
\left(\mathrm{n}_{1}=177\right) \\
\left(\mathrm{n}_{2}=176\right)\end{array}$} & \multicolumn{2}{|c|}{$\begin{array}{c}\text { Yes } \\
\left(\mathrm{n}_{1}=100\right) \\
\left(\mathrm{n}_{2}=95\right)\end{array}$} & \multicolumn{2}{|c|}{$\begin{array}{c}\text { No } \\
\left(\mathrm{n}_{1}=120\right) \\
\left(\mathrm{n}_{2}=125\right)\end{array}$} & & & \\
\hline & & $M d n$ & $I Q R$ & $M d n$ & $I Q R$ & $M d n$ & $I Q R$ & $M d n$ & $I Q R$ & & & \\
\hline \multirow{2}{*}{ Condition } & I & 3 & 3 & 3 & 2 & 2 & 1 & 2 & 2 & 4.99 & 0.172 & 0.010 \\
\hline & II & 2 & 2 & 3 & 2 & 2 & 1 & 2 & 1 & 5.83 & 0.120 & 0.012 \\
\hline \multirow{2}{*}{ Energy } & I & 3 & 1 & 3 & 2 & 3 & 2 & 3 & 2 & 0.98 & 0.807 & 0.002 \\
\hline & II & 3 & 2 & 3 & 2 & 3 & 2 & 3 & 2 & 0.64 & 0.887 & 0.001 \\
\hline \multirow{2}{*}{ Nutrition } & I & 3 & 2 & 3 & 2 & 2 & 2 & 3 & 2 & $35.61^{* * *}$ & $0.000^{\mathrm{c}, \mathrm{d}}$ & $0.072^{* * *}$ \\
\hline & II & 3 & 2 & 3 & 2 & 2 & 2 & 2 & 1 & $34.27^{\text {*** }}$ & $0.000^{\mathrm{c}, \mathrm{d}}$ & $0.069^{* *}$ \\
\hline \multirow{2}{*}{ Education } & I & 5 & 2 & 5 & 2 & 4 & 2 & 4 & 3 & $18.93^{* * * *}$ & $0.000^{\mathrm{c}, \mathrm{d}}$ & $0.038^{*}$ \\
\hline & II & 5 & 2 & 5 & 2 & 3.5 & 3 & 4 & 2 & $42.40^{* * * *}$ & $0.000^{\mathrm{c}, \mathrm{d}}$ & $0.086^{* *}$ \\
\hline \multirow{2}{*}{ Total } & I & 14 & 5 & 14 & 5 & 12 & 4 & 13 & 5.5 & $26.94^{* * * *}$ & $0.000^{\mathrm{c}, \mathrm{d}}$ & $0.055^{*}$ \\
\hline & II & 14 & 6 & 14 & 6 & 11 & 5 & 12 & 5.5 & $31.54^{* * *}$ & $0.000^{\mathrm{c}, \mathrm{d}}$ & $0.064^{\text {** }}$ \\
\hline
\end{tabular}

Legend: $\mathrm{n}_{1}$ - number in measurement I, $\mathrm{n}_{2}$ - number in measurement II, Mdn - median, IQR - interquartile range, $\mathrm{H}$ - Kruskal-Wallis test, $\eta^{2}$ - "effect size" coefficient, * $\mathrm{p}<0.05$ (u $\eta^{2}$ low), ${ }^{* *} \mathrm{p}<0.01$ (medium), ${ }^{* * *} \mathrm{p}<0.001$ (high), a - significant differences between boys meeting and not meeting PA recommendations, $\mathrm{b}$ - significant differences between girls meeting and not meeting PA recommendations, $\mathrm{c}$ - significant differences between boys and girls meeting PA recommendations, $d$ - significant differences between boys and girls not meeting PA recommendations 


\section{Fig. 1}

Knowledge in girls $(n=275)$ and boys $(n=220)$ meeting recommendations for weekly physical activity in the first and the second measurement

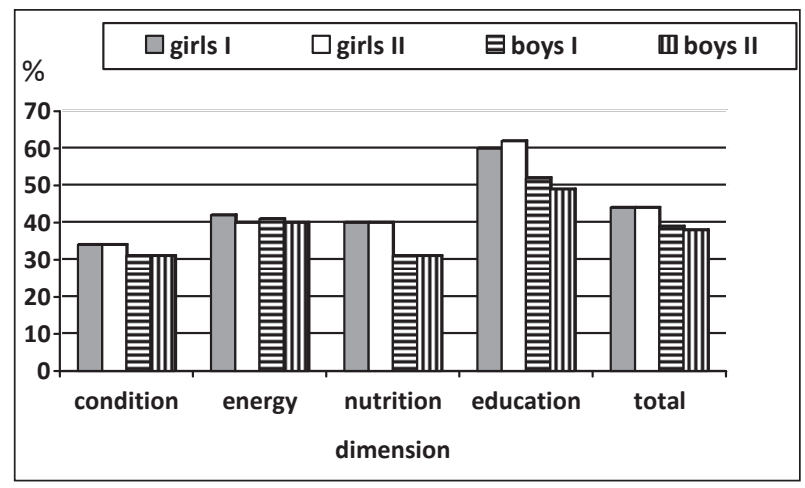

The lowest success was identified in boys in the dimensions of condition and nutrition and in girls in the dimension of condition. The biggest differences between girls' and boys' knowledge was found in the dimension of nutrition. The energy dimension is relatively stable in all groups with approximately $40 \%$ of successful results. This dimension relates to energy output connected with resting metabolism or during various types of exercising.

Boys declared on average more weekly PA (in the first measurement 11,386 METs and in the second measurement 11,393 METs) than girls (in the first measurement 8,891 METs and in the second measurement 9,992 METs).

Between the first and the second measurement, we identified lower, but statistically significant correlation in knowledge test $r_{s}=0,472$ and in questionnaire $r_{s}=0,412$.

\section{DISCUSSION}

\section{Knowledge}

Despite the fact that the questions of the Comprehensive test are based on the curriculum of ninth or tenth grade, it is difficult for the 15-16 year-old pupils, which is apparent in the low percentage of successful answers. The most difficult questions are found in the dimension of condition both for Polish and Czech pupils (Vašíčková, Neuls, Frömel, Lokvencová, Vašíček, \& Skočovská, 2009).

In one comparable study by Vašičcková, Neuls, and Frömel (2011), in the dimension of condition, Czech boys reached in $10 \%$ better results than Polish boys (the same applies to the dimension of nutrition), and in girls, Czech girls showed in $7.5 \%$ better score than Polish girls in the dimension of condition. In the education dimension, the biggest differences were found in boys with $16.5 \%$ better results in Czech students.
Pupils show very low knowledge especially in the area of volume and intensity of physical activity and load. Boys gave better answers than girls only in the case of the selection of type of exercises for overweight individuals. On the other hand, girls showed better results in questions regarding food intake, reducing weight, and in other questions. Generally, topics regarding nutrition and healthy diet are not discussed properly enough at schools. It is necessary to include these issues into school education programs within the interdisciplinary approach to teaching because they are useful in praxis and everyday life.

\section{Questionnaire IPAQ}

Questionnaires assessing physical activity can serve teachers and pupils also in terms of enhancing the awareness of healthy lifestyle and can contribute to selfreflection which can assist in making positive changes in lifestyle. The estimated level and structure of PA reflects present findings (Frömel et al., 2007).

Girls show less vigorous and moderate PA than boys but are more active in walking, which has been also confirmed by findings by Rangul, Holmen, Kurtze, Cuypers, and Midthjell (2008) who applied the same IPAQ questionnaire in Norwegian adolescents aged 13-18 years. Higher walking activity was not found in girls who showed better estimation of the caloric expenditure for the given time of walking and the responding consumption of selected food.

\section{Subject and thematic integration as a prerequisite of "literacy in healthy lifestyle"}

The results obtained on the basis of pupils' answers in the knowledge test are supported by general statements that present school does not still connect sufficiently education with students' needs outside of school (Beyer, 2008). Especially, curricula of physical education are insufficient in providing activities which would motivate students to higher physical activity unless they themselves join in some physically oriented program outside of school (Beyer, 2008). Promoting lifetime participation in physical activity is a major goal of $\mathrm{PE}$, which study by Fairclough (2002) considered in the context of curricular and extra-curricular activities. The questions in the Comprehensive test are based especially on topics taught in physical education, biology, chemistry, and health education, which makes the connection between lessons and pupils' life outside of school a challenge especially to teachers of these subjects. The literacy in the area of physically active and healthy lifestyle in pupils is a competence which transfers also to other subjects. These issues are of concern also in the neighbouring countries as was shown in a similar study carried out in the Czech Republic (Vašíčková, Chmelík, Frömel, \& Neuls, 2009). 


\section{CONCLUSION}

The results of the study have confirmed that boys show higher total weekly PA than girls. On the other hand girls show better knowledge related to physically active and healthy lifestyle. In total, knowledge about healthy lifestyle is inadequate and does not respond to curricular requirements in physical education and biology. Better knowledge acquisition about healthy lifestyle requires more effective application of subject and thematic integration and the connection between theoretical knowledge about physical activities and diet with the lifestyle of girls and boys.

\section{ACKNOWLEDGEMENTS}

The study has been supported by the research grant from the Ministry of Education, Youth and Sports of the Czech Republic (No. MSM 6198959221) "Physical Activity and Inactivity of the Inhabitants of the Czech Republic in the Context of Behavioral Changes" and a research grant from AWF Katowice - "Physical activity: An irreplaceable element of healthy lifestyles of young people" [No. AN-522-5/2009].

\section{REFERENCES}

Andersen, L. B., Harro, M., Sardinha, L. B., Froberg, K., Ekelund, U., Brage, S. et al. (2006). Physical activity and clustered cardiovascular risk in children: A cross-sectional study (The European Youth Heart Study). Lancet, 368(9532), 299-304.

Anderson, K. D., Chad, K. E., \& Spink, K. S. (2005). Osteoporosis knowledge, beliefs, and practices among adolescent females. Journal of Adolescent Health, 36, 305-312.

Bauman, A. E., Bull, F. C., Chey, T., Craig, C. L., Ainsworth, B., E., Sallis, J. F. et al. (2009). The international prevalence study on physical activity: Results from 20 countries. International Journal of Behavioral Nutrition and Physical Activity, 6(1), 21.

Beyer, R. (2008). Restructuring the secondary physical education curriculum to meet new challenges. Journal of Physical Education, Recreation \& Dance, 79(9), 27-32.

Cohen, J. (1988). Statistical power analysis for the behavioral sciences (2nd ed.). New York, NY: Lawrence Erlbaum Associates.

Cerin, E., Saelens, B. E., Sallis, J. F., \& Frank, L. D. (2006). Neighborhood environment walkability scale: Validity and development of a short form. Medicine and Science in Sports and Exercise, 38(9), 1682-1691.

Craig, C. L. et al. (2003). International Physical Activity Questionnaire: 12 country reliability and validity.
Medicine and Science in Sports and Exercises, 35(8), 1381-1395.

De Meester, F., van Lenthe, F. J., Spittaels, H., Lien, N., \& De Bourdeaudhuij, I. (2009). Interventions for promoting physical activity among European teenagers: A systematic review. International Journal of Behavioral Nutrition and Physical Activity, 6, 82.

Fairclough, S. (2002) Promoting lifetime physical activity through physical education. British Journal of Teaching Physical Education, 33(2), 38-45.

Frömel, K., Chmelík, F., Bláha, L., Feltlová, D., Fojtík, I., Horák, S. et al. (2007). Pohybová aktivita české mládeže: Koreláty intenzivní pohybové aktivity. Česká kinantropologie, 11(4), 49-55.

Frömel, K., Formánková, S., \& Sallis, J. F. (2002). Physical activity and sport preferences of 10 to 14 year old children: A 5 year prospective study. Acta Universitatis Palackianae Olomucensis. Gymnica, 32(1), 11-16.

Gavarry, O., Giacomoni, M., Bernard, T., Seymat, M., \& Falgairette, G. (2003). Habitual physical activity in children and adolescents during school and free days. Medicine and Science in Sports and Exercise, $35(3), 525-531$.

Knox, G. et al. (2009). A cross-curricular physical activity intervention to combat cardiovascular disease risk factors in 11-14 year olds: "Activity knowledge circuit”. BMC Public Health, 9, 466.

Mohr, D. J., Townsend, J. S., \& Pritchard, T. (2006). Rethinking middle school physical education: Combining lifetime leisure activities and sport education to encourage physical activity. Physical Educator, 63(1), 18-29.

Rangul, V., Holmen, T. L., Kurtze, N., Cuypers, K., \& Midthjell, K. (2008). Reliability and validity of two frequently used self-administered physical activity questionnaires in adolescents. BMC Medical Research Methodology, 8, 1-10.

Saelens, B. E., Sallis, J. F., Black, J. B., \& Chen, D. (2003). Neighborhood based differences in physical activity: An environment scale evaluation. American Journal of Public Health, 93(9), 1552-1558.

Sanchez, A., Norman, G. J., Sallis, J. F., Calfas, K. J., Cella, J., \& Patrick, K. (2007). Patterns and correlates of physical activity and nutrition behaviors in adolescents. American Journal of Preventive Medicine, 32(2), 124-130.

Sheskin, D. J. (2007). Handbook of parametric and nonparametric statistical procedures. Boca Raton: Chapman \& Hall/CRC.

The IPAQ group. (n. d.). The International Physical Activity Questionnaire. Retrieved 27. 12. 2011 from the World Wide Web: https://sites.google.com/site/ theipaq/

Trudeau, F., \& Shephard, R. J. (2008). Physical education, school physical activity, school sports and 
academic performance. International Journal of Behavioral Nutrition and Physical Activity, 5, 10.

Vašičková, J., Chmelík, F., Frömel, K., \& Neuls, F. (2009). Vztah mezi vědomostmi o problematice pohybové aktivity a realizovanou pohybovou aktivitou u středoškolských studentů. Tělesná kultura, 32(2), 33-44.

Vašíčková, J., Neuls, F., \& Frömel, K. (2011). Comprehensive test in school physical education at secondary schools in the Czech Republic: Standardization and verification. Acta Universitatis Palackianae Olomucensis. Gymnica, 40(4), 7-14.

Vašíčková, J., Neuls, F., Frömel, K., Lokvencová, P., Vašíček, J., \& Skočovská, G. (2009). Zjištování úrovně znalostí o problematice zdraví a pohybové aktivity prostřednictvím vědomostního testu na středních školách (pilotní studie). In V. Mužík \& V. Süss (Eds.), Tělesná výchova a sport mládeže v 21. století (pp. 116-125). Brno: Masarykova univerzita.

\section{VĚDOMOSTI ADOLESCENTNÍCH DĚVČAT A CHLAPCŮ VZTAHUJÍCÍ SE K POHYBOVĔ AKTIVNÍMU A ZDRAVÉMU ŽIVOTNÍMU STYLU}

(Souhrn anglického textu)

VÝCHODISKA: Vědomosti adolescentů o pohybově aktivním a zdravém životním stylu jsou jedním $\mathrm{z}$ důležitých faktorů vztahu k pohybové aktivitě (PA) a celoživotní prevalence k zdravému životnímu stylu.

CÍLE: Cílem výzkumu bylo zjistit rozdíly ve vědomostech děvčat a chlapců o zdravém životním stylu a vztah mezi deklarovanou týdenní pohybovou aktivitou a základními vědomostmi vztahujících se ke zdravému životnímu stylu.

METODIKA: Výzkumu na 14 vybraných školách Katowického regionu se celkem zúčastnilo 275 děvčat $(15,8 \pm 0,9$ years $)$ a 220 chlapců $(15,8 \pm 0,8$ years $)$. Úroveň vědomostí o zdravém životním stylu byla zjištována polskou verzí testu „Vědomostní test o zdraví a pohybové aktivitě “ a úroveň týdenní PA dotazníkem IPAQ - delší verze, a to s opakováním po šesti týdnech. Analyzovány byly asociace mezi vědomostmi, pohlavím a plněním doporučení pro PA (nejméně $3 \times 20$ min. intenzivní a $5 \times 30$ min. středně zatěžující týdenní PA).

VÝSLEDKY: Děvčata mají více vědomostí vztahujících se k pohybově aktivnímu a zdravému životnímu stylu než chlapci $(U=5.04 ; p=0.000 ; d=0.493)$, což se potvrdilo i v opakovaném šetření $(U=5.54 ; p=0.000$; $\mathrm{d}=0.505)$. Statisticky i prakticky signifikantní rozdíly mezi děvčaty a chlapci byly zjištěny ve prospěch děvčat v dimenzi nutriční, edukační a i celkově. Mezi vědomostmi a plněním doporučení pro PA nebyly zjištěny významné asociace ani u děvčat, ani u chlapců. Chlapci deklarovali více týdenní PA (v prvním měření
11386 METů a druhém měření 11393 METů) než děvčata (v prvním měření 8891 METů a druhém měření 9992 METů).

ZÁVĚRY: Základní vědomosti o zdravém životním styly jsou nevyhovující z hlediska kurikulárních požadavků (zejména tělesné výchovy a biologie). Hlubší osvojování vědomostí o zdravém životním stylu vyžaduje integrovaný mezipředmětový př́stup a efektivnější propojení osvojování vědomostí o pohybové aktivitě, stravování a dalších zdravotně preventivních opatřeních s životním stylem děvčat a chlapců.

Kličová slova: tělesná výchova, pohybová aktivita, vědomostní test, mezipředmětová integrace.

Mgr. Jana Vašíčková, Ph.D.

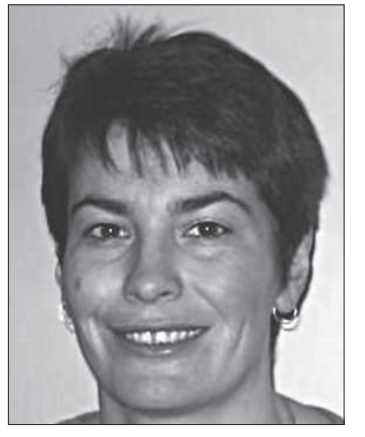

Palacký University, Olomouc Faculty of Physical Culture tř. Míru 115 77111 Olomouc Czech Republic

Education and previous work experience 1998 - Palacký University, Faculty of Physical Culture (Mgr.).

1998-2001 doctoral student; Palacký University, Faculty of Physical Culture.

2002 - Palacký University, Faculty of Physical Culture (Ph.D.).

2001-2002 - teacher at private vocational school, Uničov.

Since 2007 - research and pedagogical assistant at Palacký University, Faculty of Physical Culture, Institute of Active Lifestyle, Olomouc, Czech Republic.

\section{Scientific orientation}

Research in Kinanthropology; focus on Physical Education at different types of schools. Teaching methodology and pedagogy within Faculty undergraduate program. Focus on data analysis, statistics, sport pedagogy and teaching PE and analysis of physical activity.

\section{First-line publication}

Vašíčková, J., Roberson, D. Jr., \& Frömel, K. (2012). The educational and socio-demographic determinants of physical activity in Czech adults. Human Movement, 13(1), 54-64.

Frömel, K., El Ansari, W., \& Vašíčková, J. (2009). The impact of teaching physical education to Czech school children using progressive teaching approaches: Findings of a four-year study. Central 
European Journal of Public Health, 17(3), 161-168.

Pelclová, J., El Ansari, W., \& Vašíčková, J. (2010). Is participation in after school physical activity associated with increased total physical activity? A study of high school pupils in the Czech Republic. International Journal of Environmental Research and Public Health, 7(7), 2853-2865. doi:10.3390/ijerph7072853.

Pelclová, J., El Ansari, W., \& Vašíčková, J. (2010). Study of day, month and season pedometer determined variability of physical activity of high school pupils in the Czech Republic. Journal of Sport Science and Medicine, 9(3), 490-498.

Vašíčková, J., \& Frömel, K. (2011). Healthy and active lifestyle of Czech adolescents: Ideas for changes in
PE curriculum. In J. Labudová \& B. Antala (Eds.), Healthy active life style and physical education (pp. 18-26). Bratislava: END, s. r. o.

Vašíčková, J., \& Frömel, K. (2009). Pohybově aktivní životní styl adolescentů České republiky: Východiska pro kurikula tělesné výchovy. Česká kinantropologie, 13(4), 70-76.

Vašíčková, J., Svozil, Z., Nykodým, J., Lukavská, M., \& Bláha, L. (2012). Knowledge about physical activity and health in undergraduate preparation of physical education teachers at Czech universities. In J. Vašíčková \& B. Antala (Eds.), Professionals and volunteers in physical education, (pp. 45-50). Bratislava: END, s. r. o. 